\title{
The potential of fragipans in sustaining pearl millet during drought periods in north-central Namibia
}

\author{
Brice Prudat, Wolfgang Fister, Lena Bloemertz, Juliane Krenz, and Nikolaus J. Kuhn
}

Physical Geography \& Environmental Change Research Group, Department of Environmental Sciences, University of Basel, Klingelbergstrasse 27, 4056 Basel, Switzerland

Correspondence: Brice Prudat (brice3d2010@gmail.com)

Received: 9 April 2021 - Revised: 6 November 2021 - Accepted: 9 November 2021 - Published: 14 January 2022

\begin{abstract}
Sandy soils with fragipans are usually considered poorly suited for agriculture. However, these soils are cultivated in Namibia as they can secure a minimum harvest during droughts. In order to understand the hydrological influence of fragipans in these soils, Ehenge, their soil moisture content was measured for 4 months. These data were then compared to a deep soil without fragipan, Omutunda, which is more productive during normal years but less productive during droughts.

The results illustrate that the combination of sandy topsoil and shallow fragipan has beneficial effects on plant-available water during dry periods.

Three reasons can be determined: (i) high infiltration rate in the sandy topsoil, (ii) prevention of deep drainage by the fragipan, and (iii) limitation of evaporation losses through the sand. Consequently, transferring these findings to other dry, sandy areas with fragipans, with respective consequences on farming practices, crop productivity, and food security, should be possible.
\end{abstract}

\section{Introduction}

Droughts or sustained dry periods are a common feature in semi-arid regions of Namibia and can occur more or less every other year (Keyler, 1995). They are often accompanied by significant crop failures and therefore pose a threat to local food security. For example, during the 2012/2013 drought, one of the driest rainy seasons on record, about one-third of the Namibian population was classified as food insecure (Sivakumar, 2013). The impact on the population was particularly strong in the north-central regions, where many people still rely on subsistence crop production. Such droughts with all their negative implications will most likely increase in frequency as a result of climate change (IPCC, 2021). In addition to these extreme drought events, plant water availability in north-central Namibia is in general highly variable over the cultivation season and from one year to another (Rockström and De Rouw, 1997). Water stress, if occurring during the flowering and grain filling period, strongly reduces crop yield (Vadez, 2014; Vereecken et al., 2008), while crops have better capacity to compensate for water shortage during their early growth phases (Rockström and De Rouw, 1997).
This high variability and often restricted plant-available water cause severe risk for farmers to experience reduced crop yields. This explains the reluctance of farmers to use expensive inputs, usually in the form of fertilizers, to increase soil fertility and thus productivity (Rockström et al., 2010; Rurinda et al., 2013).

\subsection{Local farmers' knowledge on soil hydrology}

Because of its importance for plant growth, hydrological properties such as lack of plant-available water or waterlogging in the soil are used by farmers of semi-arid regions to evaluate soil quality (Niemeijer and Mazzucato, 2003). In north-central Namibia, farmers even differentiate local soil types based on their hydrology (Prudat et al., 2018, 2020). One such soil is Ehenge, which is described as experiencing severe waterlogging during heavy rainfall events, which leads to excess water conditions over prolonged time periods, impeding crop growth and crop development. Together with usually very high sand and low carbon contents in the topsoil, Ehenge would generally be considered poorly suited for agricultural use. However, despite these poor conditions, Ehenge 
soils are commonly cultivated with pearl millet (Pennisetum arvense) or sorghum (Sorghum bicolor), as they show favourable water conditions in case of drought (Hillyer et al., 2006). The farmers explain that "crops remain fresh" on this soil type during dry periods. In various semi-arid regions in Africa, the presence of soils with specific hydrological characteristics has been described and is cultivated by farmers, despite their low chemical fertility in comparison to other local soils (Krogh and Paarup-Laursen, 1997). The investments in these soils represent a sort of insurance of a minimal harvest in dry years, when the more fertile soils fail to sustain the expected harvest (Hillyer et al., 2006; Krogh and PaarupLaursen, 1997).

\subsection{Fragipans in north-central Namibia}

The hydrological characteristics of Ehenge soils are most likely associated with the presence of a compact and poorly permeable soil layer, locally called Olumha. It is usually situated anywhere between 0.15 and $1 \mathrm{~m}$ deep in the soil profile and is very hard and compact when dry (Prudat et al., 2018). It is assumed that the Olumha layer acts like a fragipan, which has been described mostly in the Northern Hemisphere in relation to glacial till, but it has also been described in the Chad Basin (Lamotte et al., 1997), in Australia (Chartres, 1985), and in South Africa (Francis et al., 2007). Fragipans are compacted layers that can result from various processes (freezing-thawing, pressure, swelling-drying) that exclude the plough pan (Soil Survey Staff, 1999). These layers could be similar to hard-setting layers, which were described by Daniells (2012), and generally are underlying a sandy topsoil layer with high hydraulic conductivity. The lower macroporosity in fragipans in comparison to overlying loose sand layers implies a lower hydraulic conductivity (Lamotte et al., 1997). The lower conductivity tends to inhibit deep drainage and thus can increase water availability for plants during dry periods through the storage of water within the root zone. Given that water in soils is often the limiting factor for agricultural production in semi-arid rainfed agriculture, understanding of such soil-type-specific hydrology is a prerequisite to increasing agronomic efficiency and economic returns and to promote sustainable agricultural intensification (Leenaars et al., 2015; Vanlauwe et al., 2015).

The farmers' perception of the hydrological characteristics of Ehenge, including the potential impact of the Olumha layer (further called fragipan) on soil hydrology, has not been studied in a quantitative way for north-central Namibia yet. However, information on the interactions between soil texture, infiltration, and plant-available water is vital in order to connect local farmers' assessment of soil quality to the general assessment of a soil's yield potential in agronomy.

In order to investigate the influence of the fragipans in Ehenge soils on water availability for plants, its soil moisture and water dynamics were measured during a 4-month period from February to June 2014. For comparison, these results were then related to measurements in an Omutunda soil, which is generally considered to be more productive due to its deep profile, finer texture with greater cation exchange capacity, and higher water storage capacity. The following research questions were formulated: (i) under which conditions are fragipans in Ehenge soils beneficial for the amount of plant-available water? (ii) Is the presence of fragipans able to mitigate plant water stress under drought conditions?

\section{Materials and methods}

\subsection{Site selection}

The climate of north-central Namibia is described as semiarid subtropical with a pronounced rainy season, which generally occurs from November to April. Average annual rainfall is between 450 and $500 \mathrm{~mm}$ and is usually expected during this period. However, there is a very large inter- and intraannual variability of rainfall (Mendelsohn et al., 2013). The soil substrate in this region consists of the Kalahari sands (Miller et al., 2010) and fluvial sediments from the Cuvelai River that created a network of wide yet shallow ephemeral water channels (locally called Iishana). Non-commercial and subsistence agriculture are the most important land use types within the region and commonly involve the cultivation of small-scale (i.e. 1-4 ha), rain-fed pearl millet (Pennisetum glaucum (L.) R. Br.; Mendelsohn et al., 2000). Average pearl millet yields reach $220 \mathrm{~kg} \mathrm{ha}^{-1}$ in the Ohangwena region in north-central Namibia. Amounts are highly variable from year to year and from household to household, due to low soil fertility, heterogeneous nutrient supply, irregular rainfall, and pests (Central Bureau of Statistics, 2003; Mendelsohn et al., 2000; Rukandema et al., 2009). Two soils, located in a pearl millet field owned by a single family in the village of Ondobe (Ohangwena region), were studied (Fig. 1). At both locations, disc harrow ploughing and sowing of pearl millet were performed the same day during late December 2013, and both soils were neither subsequently hoed nor weeded before sowing. The plants reached a three- to five-leaf stage at the time when the measurements started. The lack of rain since January caused initial wilting of the plants on Oтиtunda, whereas on Ehenge no indication of water stress was visible.

\subsection{Soil description}

This study focuses on the hydrological characteristics of the soil, locally called Ehenge. Based on the perception of local farmers, this soil has good water storage capability and is, therefore, important for farmers during droughts. According to the World Reference Base (IUSS Working Group WRB, 2014), this soil was classified as Eutric Sodic Protoargic Arenosol (aridic). For comparison, a nearby soil, Omutunda (Calcaric Regosol (loamic ochric), was chosen to serve as a reference because of its deep soil profile without fragipan 

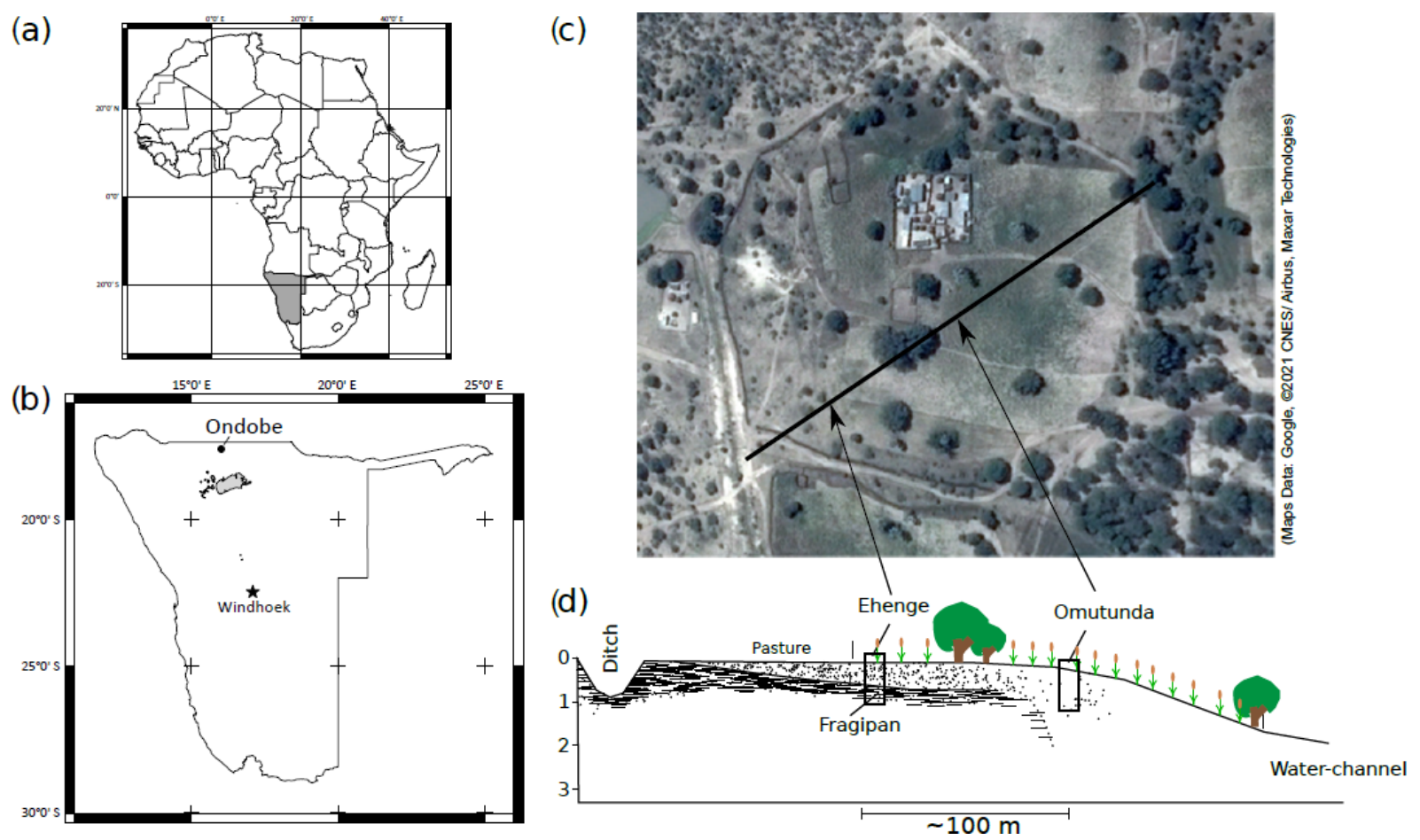

Figure 1. Location of the farm near Ondobe village. (a) Overview of Africa; (b) Overview of Namibia (grey polygon marks the Etosha pan); (c) Location of soil profiles on the farm and depiction of transect on an underlying aerial picture from Google Maps (map data: Google (C) 2021 CNES/Airbus, Maxar Technologies). (d) Schematic transect of the studied soil profiles location and the relative position of the fragipan.

and much better chemical fertility and crop productivity during years with normal rainfall and reported poor yields during droughts. The Ehenge is located on a flat area close to the limit of the field with bordering grasslands. Compact Bx and Bgx horizons (fragipan) are present from $50 \mathrm{~cm}$ downwards (Fig. 2). Local farmers describe the fragipans as "very hard when dry" but "friable when moist" (Prudat et al., 2018). Overlying are a $0.5 \mathrm{~cm}$ thick dark clay horizon $(\mathrm{Bt})$ and a $7 \mathrm{~cm}$ thick eluvial horizon (E at $42-49 \mathrm{~cm}$ ). The upper B2 and B1 as well as the ploughing horizons (Ap) are very sandy (above $92.5 \%$ ) and poorly differentiated. From the eluvial horizon to the fragipan, a sudden increase of BD from 1.54 to $1.70 \mathrm{~g} \mathrm{~cm}^{-3}$ can be observed, indicating a change in water permeability. The Omutunda reference soil is located closer to the farm at a distance of about $100 \mathrm{~m}$ on a gentle slope. The texture is also dominated by sand, but the proportion of fines increases with depth. Sand contents decrease from $87.2 \%$ in Ap horizons to $75.6 \%$ in Bck 3 horizon at $50 \mathrm{~cm}$ depth (Fig. 3). Local farmers describe this soil as dark and hard soil. It is the most fertile soil in the area to cultivate pearl millet. No hydrologically significant differences in bulk density or permeability can be observed in the profile.

\subsection{Data collection and processing}

For each soil type, Ehenge and Omutunda, one soil profile was prepared and sampled for differentiation of diagnostic horizons and characterization of soil properties. In addition, these profiles were used for installation and measurement of soil moisture and temperature. Near each profile, automatic rain gauges were installed to measure rainfall amounts and intensities. The setup, sampling, measurements, and processing of the data are described in the following subsections.

\subsubsection{Soil properties}

The soil bulk density (BD), acidity ( $\mathrm{pH}$ ), soil colour, soil texture, and total organic carbon (TOC) were analysed in the soil laboratory of the Physical Geography and Environmental Change Research Group at the University of Basel. Prior to the analysis, all bulk soil samples were dried at $40^{\circ} \mathrm{C}$ and passed through a $2 \mathrm{~mm}$ sieve for removal of stones and organic components. Bulk density was determined by drying undisturbed soil samples at $40^{\circ} \mathrm{C}$, which were obtained by using $100 \mathrm{~cm}^{3}$ sample cores. $\mathrm{pH}$ was measured in an aqueous solution with a Seven Excellence pH meter (MettlerToledo, Columbus, OH, USA), and particle size distribution was analysed using a Malvern Mastersizer 2000 (Malvern Panalytical, Almelo, the Netherlands) without prior destruc- 

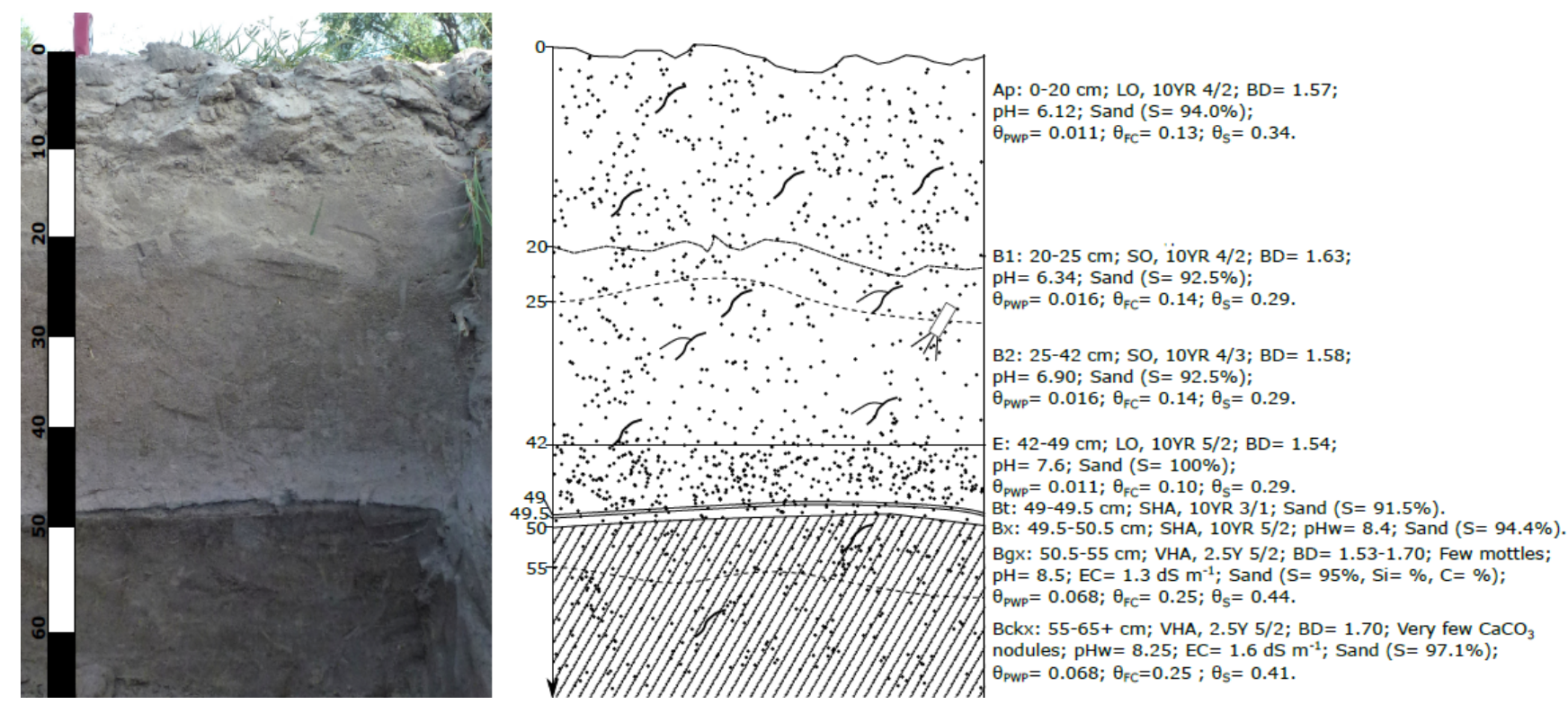

Figure 2. Soil profile of the studied Ehenge soil, described as Eutric Sodic Protoargic Arenosol (aridic) (IUSS Working Group WRB, 2014). Bulk density (BD) is in $\mathrm{g} \mathrm{cm}^{-3}$, acidity $(\mathrm{pH})$, sand content $(\mathrm{S})$ in $\%$, and volumetric water content at permanent wilting point $\left(\theta_{\mathrm{PWP}}\right)$, field capacity $\left(\theta_{\mathrm{FC}}\right)$, and saturation $\left(\theta_{\mathrm{S}}\right)$ in $\mathrm{cm}^{3} \mathrm{~cm}^{-3}$.
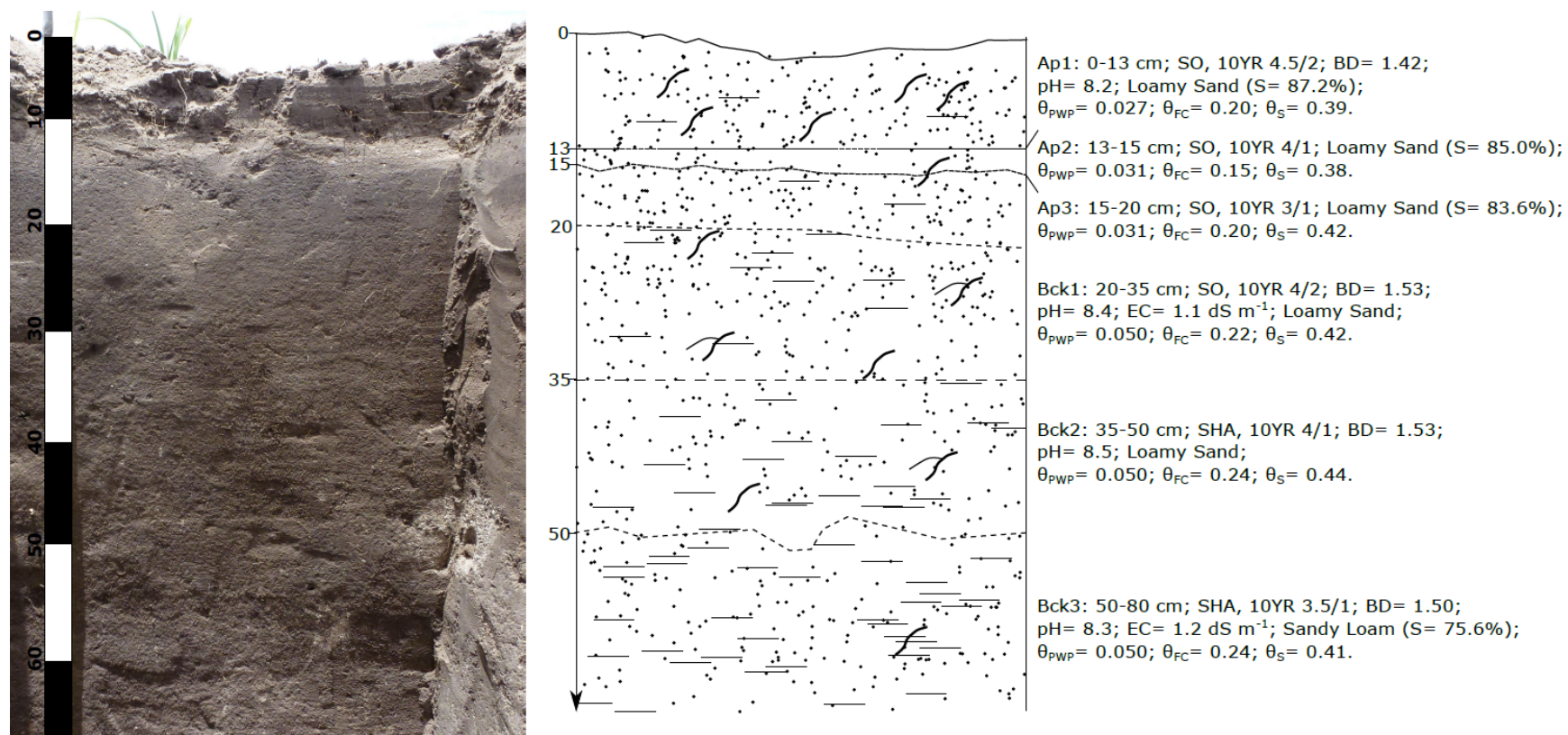

Figure 3. Soil profile of the studied Omutunda soil, described as Calcaric Regosol (loamic ochric) (IUSS Working Group WRB, 2014). Bulk density (BD) is in $\mathrm{g} \mathrm{cm}^{-3}$, acidity $(\mathrm{pH})$, sand content $(\mathrm{S})$ in $\%$, and volumetric water content at permanent wilting point $(\theta \mathrm{PWP})$, field capacity $\left(\theta_{\mathrm{FC}}\right)$, and saturation $\left(\theta_{\mathrm{s}}\right)$ in $\mathrm{cm}^{3} \mathrm{~cm}^{-3}$.

tion of organic material. Total organic carbon was measured using a RC612 carbon combustion analyser (LECO Corporation, St. Joseph, MI, USA).

Hydraulic soil properties were determined from $100 \mathrm{~cm}^{3}$ undisturbed sample cores using the pressure plate method (Dane and Topp, 2002) and modelled with the van Genuchten closed-form equation (van Genuchten, 1980). The models were used to estimate volumetric water content $(\theta)$ at permanent wilting point $\left(-1.5 \mathrm{MPa} ; \theta_{\mathrm{PWP}}\right)$ and at field capacity $\left(\theta_{\mathrm{FC}}\right)$ (Nemes et al., 2011) for each horizon of the soil profile. The hydraulic conductivity at saturation was measured 
for the fragipan from an undisturbed sample using the falling head method with a $50 \mathrm{~cm}$ head (Dane and Topp, 2002).

\subsubsection{Soil moisture monitoring}

The two soil moisture measurement stations were equipped with Decagon rainfall and soil moisture sensors (Meter Group AG, Munich, Germany) and, unless not clearly specified in the description below, were set up in exactly the same way. Volumetric soil moisture content $\left(\theta_{\mathrm{TDR}}\right)$ was measured by 5-TM and EC-5 moisture probes ( $3 \mathrm{~h}$ interval), and the amount and intensity of rainfall was measured using rain gauges, type ECRN-100 (1 min interval). Measurements were conducted continuously for $120 \mathrm{~d}$ in total, from 12 February to 13 June 2014. It was not possible to measure antecedent soil moisture and rainfall before that time, because the farmers did not authorize installation of the measurement stations in the field before ploughing. The rainfall and soil moisture records were aggregated into daily data, using the arithmetic mean for $\theta_{\mathrm{TDR}}$ and the sum of precipitation for each interval.

a Soil moisture measurements. For Ehenge, EC-5 moisture probes were installed at the depth of 25,42 , and $50 \mathrm{~cm}$, in order to capture the water content dynamics within the B horizons, at the top of the E horizon, and at the upper limit of the fragipan. For Omutunda, the depths were 25,42 , and $64 \mathrm{~cm}$. The EC-5 moisture probes were installed $30 \mathrm{~cm}$ into the undisturbed soil from the sidewall of the soil pit using a pilot tool. This approach was chosen to keep the disturbance of the soil to a minimum. By using these depths, the moisture probes provide an understanding of the evolution of the water content in the pearl millet root zone (Kizito et al., 2006; Zegada-Lizarua et al., 2005). The pit was refilled after sensor installation to prevent increased evaporation.

EC-5 moisture probes measured the water content indirectly through dielectric conductivity. The manufacturer equations to transform these measurements into volumetric water content and temperature values could be applied, because they are considered to be insensitive to the variations in soil mineral composition, salinity (Kizito et al., 2006; Sun et al., 2000) or bulk density (Quinones et al., 2003). Before installation of the moisture probes and at the end of the measurement period, water content was also measured using gravimetric water content $\left(\theta_{\text {grav }}\right)$ to validate the sensor measurements $\left(\theta_{\mathrm{TDR}}\right)$.

It has to be noted that due to technical problems, data collection failed in all layers for Ehenge from 17 to 25 March and also at a depth of $50 \mathrm{~cm}$ from 24 April to 8 May. b Rainfall measurements. The two high-resolution rain gauges, type Decagon ECRN-100, recorded rainfall intensity per minute at each site. For further analysis in combination with the relative available soil water (RASW), an average daily rainfall amount was calculated from both stations. This allowed for filtering spatial inhomogeneity between the two stations and to fill in measurement gaps or errors, which occurred sporadically in both individual data sets. Rainfall events below $2 \mathrm{~mm}$ of rainfall per day were excluded from display in Fig. 4 to improve the readability of the figure and because of their negligible influence on soil hydrology at the recorded depths.

c Soil temperature. Soil temperature was recorded for every minute within the measurement period by the 5-TM probes, which were installed at a depth of $5 \mathrm{~cm}$ in each profile. Since the soil surface temperature is more important for plant growth than the soil temperature itself, surface temperatures were calculated following the method by Hillel (1998, pp. 309-316). Further details about the calculation of surface temperatures are given in the cited literature and in Appendix A.

\subsection{Relative available soil water}

The relative available soil water (RASW) illustrates the plant hydrological environment better than the volumetric water content (Jensen et al., 1998). Therefore, the RASW was calculated based on the measured plant-available water, according to Eq. (1):

$\mathrm{RASW}=100 \frac{\left(\theta_{\mathrm{TDR}}-\theta_{\mathrm{PWP}}\right)}{\left(\theta_{\mathrm{FC}}-\theta_{\mathrm{PWP}}\right)}$,

where RASW is the relative available soil water, $\theta_{\mathrm{TDR}}$ is the measured volumetric water content from the moisture sensors, $\theta_{\mathrm{PWP}}$ is water content at permanent wilting point, and $\theta_{\mathrm{FC}}$ is water content at field capacity. These measures were obtained using the van Genuchten models based on pressure plate measurements.

Only few reference values could be found in the literature, which describe a negative influence of specific RASW values on plant growth. Jensen et al. (1998) show that RASW values smaller than $12 \%$ restricted Lupinus sp. from growing in sand, while RASW values smaller than $45 \%$ decreased photosynthesis activity in wheat on loamy sand (Ali et al., 1999). However, no specific value could be found for pearl millet. Therefore, a conservative RASW of $15 \%$ was chosen as a threshold, indicating negative effects on plant development in this study. RASW values above $100 \%$ suggest that the water content is above field capacity. 


\section{Results}

\subsection{Development of relative available soil water (RASW)}

During the period under study the RASW values showed high fluctuations and reflected the rainfall pattern. Especially the start of the rainy season (rainfall on 20 February) and the continuous drying of the soil layers during the dry period, following the rainfall on 6 April, can clearly be seen in Fig. 4. In general, the response time of RASW values to rainfall events increases with depth and the magnitude of response in RASW values decreases with depth. However, the hydrological situation in Ehenge needs to be looked at in more detail, because the RASW values ranged from $-13 \%$ up to $170 \%$, $5 \%$ up to $320 \%$, and $22 \%$ up to $110 \%$, for depths of 25,45 , and $50 \mathrm{~cm}$, respectively. Maximum ranges of $315 \%$ occurred at a depth of $45 \mathrm{~cm}$, which indicates that the underlying fragipan has a significant influence on soil hydrology, by preventing deep drainage and storing of water above. This becomes apparent when comparing the RASW values of Ehenge with the much lower range of values in the reference soil Omutunda. Even during very heavy rainfall events with rainfall amounts higher than $60 \mathrm{~mm} \mathrm{~d}^{-1}$, i.e. on 11 and 18 March, the maximum RASW values in Omutunda reached only $56 \%$, $48 \%$, and $43 \%$ at depths of 25,42 , and $64 \mathrm{~cm}$, respectively, but never even field capacity (RASW $=100 \%$ ).

In order to facilitate a more detailed interpretation of the available RASW data, the period under study was subdivided into three shorter periods: a short dry period in summer that started before the recording began and ended on 24 February, a rainy period until 7 April, and the beginning of the dry season (7 April to 12 June, end of data record).

\subsubsection{Short dry period in summer}

During the short dry summer period only little rainfall occurred ( $6.4 \mathrm{~mm}$ on 14 February). Since none of the sensors showed any change of signal, it is apparent that the amount was not high enough to infiltrate into deeper soil layers. Apart from the sensor at $50 \mathrm{~cm}$ depth in Ehenge, all other layers recorded RASW values below $15 \%$ during that time period and can be considered dry. Regarding the water content with depth, the two soils showed a contradictory pattern. Whereas the water content in Omutunda decreased with depth, the water content in Ehenge increased with depth. For Omutunda, this pattern was similar throughout the measurement period but changed significantly for Ehenge. We speculate that the higher moisture content at depths in Ehenge is stored water from previous rainfall events that occurred in mid-January.

\subsubsection{Rainy period}

With the beginning of rainfall on 20 February $(28 \mathrm{~mm})$ the RASW values in both soils increased and reflected the rainfall pattern for the following days. RASW values increased after rainfall and decreased afterwards due to drainage. The increase of RASW at $42 \mathrm{~cm}$ depth in Ehenge was very pronounced, with values immediately increasing above $100 \%$, indicating that the water content was above field capacity. In contrast, the reply at $25 \mathrm{~cm}$ depth was of very low magnitude. The most likely reason for this damped signal could have been a poor contact of the sensor to the soil, as a result from installation. This effect vanished completely on $11 \mathrm{March}$, after prolonged intensive rainfall (max. of $85 \mathrm{~mm} \mathrm{~d}^{-1}$ ), when all sensors in Ehenge showed RASW values above field capacity $(>100 \%)$. We attribute this change to settling and compaction of the soil when becoming wet, closing gaps around the sensors.

Throughout the rest of the rainy period the RASW values at $42 \mathrm{~cm}$ stayed highest, with minimum values above $200 \%$ and maximum values above $300 \%$. In the Omutunda, moisture showed a contrasting development over time: all RASW values stayed significantly below field capacity throughout the rainy period, with maximum values of $56 \%, 48 \%$, and $43 \%$ for the depths of 25,42 , and $64 \mathrm{~cm}$, respectively. These relatively low moisture contents reflect the very good drainage conditions in Omutunda in contrast to the Ehenge. For the rest of the rainy period, until 13 April, these conditions stayed more or less the same, although some missing data for Ehenge (17 to 25 March) impede this interpretation somewhat.

\subsubsection{Dry season}

The dry season started after the last heavy rainfall event on 6 April. The RASW values decreased at a different rate, depending on soil depth, continuously from that point onwards, until the end of the measurement period. Only the sensor at $50 \mathrm{~cm}$ in the Ehenge above the fragipan stayed at the same level until about $17 \mathrm{~d}$ later, when missing values from 24 April to 8 May prevent further interpretation. Nevertheless, this delayed response to the dry period indicates that the water in this layer is stored during drought periods.

The threshold of $100 \%$ (field capacity) was reached in Ehenge on the 9 April for the depth of $25 \mathrm{~cm}$ and around the 1 May for $42 \mathrm{~cm}$ (E horizon) as well as $50 \mathrm{~cm}$ (fragipan). In total, the RASW values stayed above $100 \%$ for 48 and 62 consecutive days in 42 and $50 \mathrm{~cm}$ depth, respectively. As mentioned above, this threshold was never reached in $\mathrm{Omu}$ tunda during the measurement period. With RASW values being much lower in Omutunda than in Ehenge, it is only at the end of the measurement period in mid-June that both soils showed similar moisture values around RASW of $15 \%$. The two small rainfall events during the dry period showed no effect on the decreasing RASW values. 

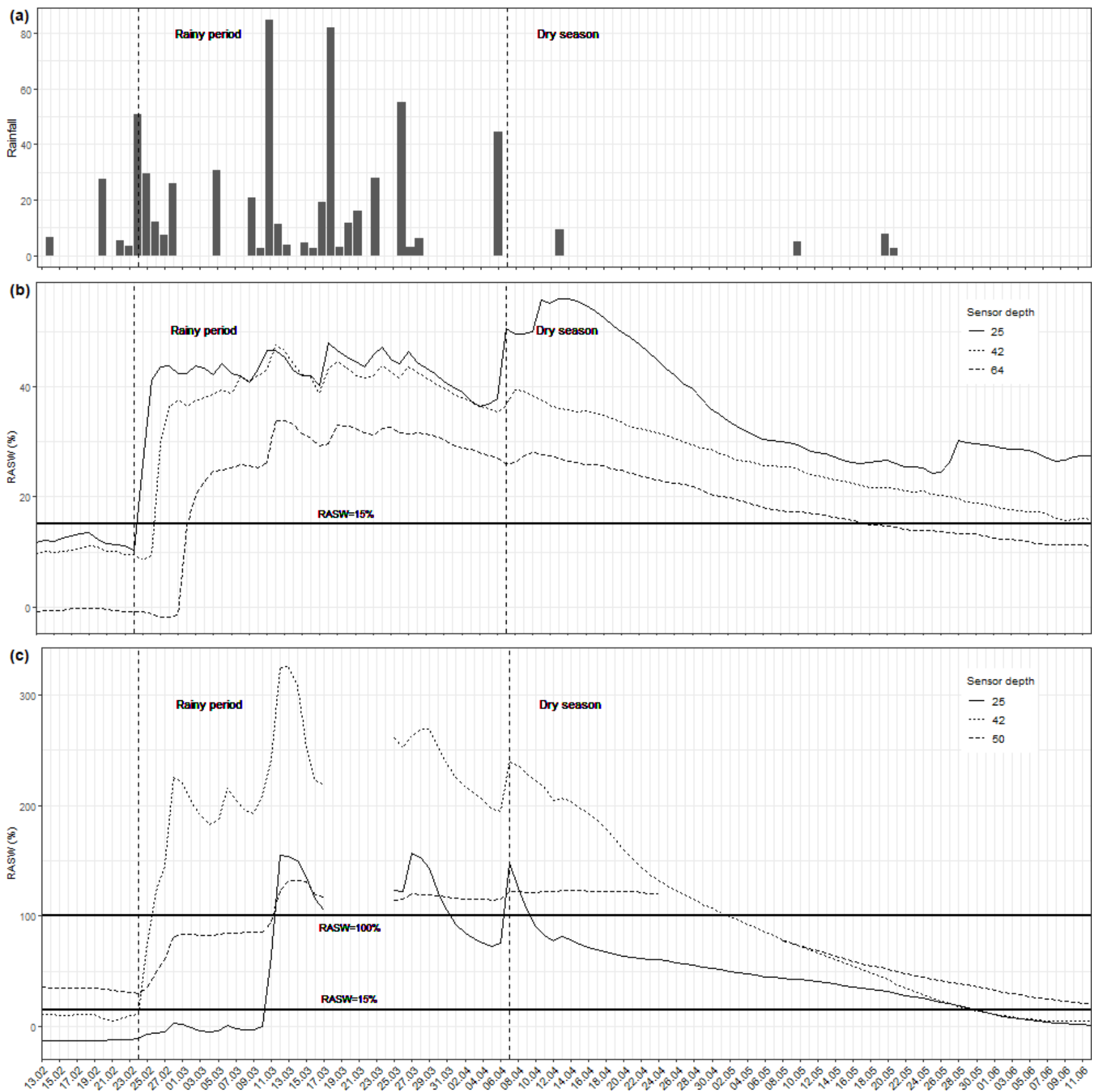

Figure 4. Data from rainfall and soil moisture measurement stations from 13 February to 13 June 2014: (a) rainfall amount (in mm per day), (b) relative available soil water content (RASW, in \%) for Omutunda, and (c) the RASW for Ehenge. Please note that the scales of the $y$ axes are different between Ehenge and Omutunda.

\subsection{Soil temperature}

The maximum soil surface temperature values show a highly variable pattern, which changes from day to day (Fig. 5). Until the beginning of April, the surface temperatures in Ehenge are generally higher than in Omutunda and exactly the opposite pattern is visible for the rest of the measurement period. During the dry period, until the first rainfall shows some ef- fect, the soil temperatures in Omutunda were between 5 and $10^{\circ} \mathrm{C}$ warmer than in Ehenge. During the rainy period this difference reversed and became much less pronounced with maximum differences of about $5{ }^{\circ} \mathrm{C}$ on rainless days. Maximum calculated surface temperatures reached values of 60.5 and $50.2{ }^{\circ} \mathrm{C}$ for Omutunda and Ehenge, respectively. 


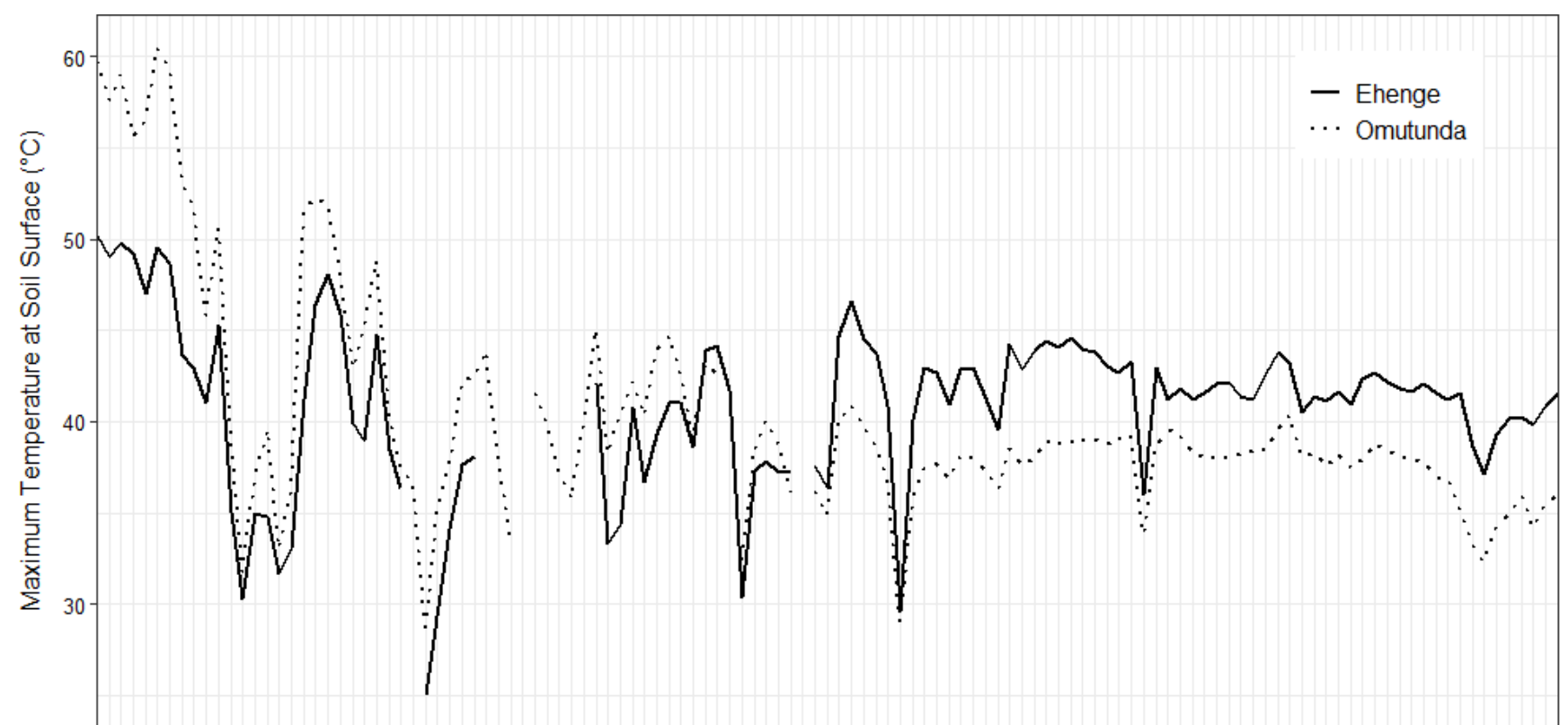

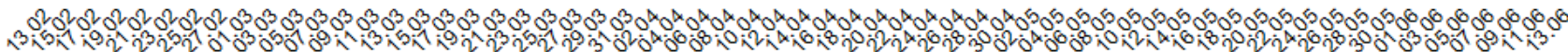

Figure 5. Maximum daily temperature at soil surface calculated using soil temperature measurements at $5 \mathrm{~cm}$ depth.

\section{Discussion}

The total rainfall amount during the 2013/2014 growing season was $580 \mathrm{~mm}$ and for the previous drought period (2012/2013) only $220 \mathrm{~mm}$, based on the climate data from Omahenene weather station, which is the closest to the test site at approximately $150 \mathrm{~km}$ distance. The measurement period can, therefore, be considered a regular year in terms of rainfall. Although this rainfall amount limits an assessment of moisture dynamics in years of drought, the positive effect of the fragipan in Ehenge on soil hydrology and water availability for plants is clearly visible in the higher RASW values in comparison to the reference soil Omutunda. By using the measurements from this investigation to develop a conceptual model of the soil hydrological behaviour of Ehenge, it is possible to quantitatively prove the value of the local farmers' knowledge about their soils in north-central Namibia. In order to do so, the results from the RASW and surface temperature measurements will be discussed here and used to outline a conceptual model to make an estimate on the development of water availability in Ehenge during droughts.

\subsection{Water and temperature stress during the dry summer period}

The short dry period before the beginning of the observations lasted for $23 \mathrm{~d}$, from 28 January to 21 February (data from Omahenene climate station). This dry period reflects rainless summer periods, which occur almost every year but may last even longer. For example, a dry summer period occurred in
2013 with less than $10 \mathrm{~mm}$ of rainfall for $40 \mathrm{~d}$ in Omahenene. In 2014, this dry period started around a month after sowing, when the crops were roughly between the three- and five-leaf stage. The measurements corroborate the observed drought stress suffered by the plants at that time, because the RASW values in the Omutunda were below $15 \%$ during that period. In contrast, daytime wilting did not occur on Ehenge, despite the fact that all layers, except the fragipan $(50-55 \mathrm{~cm})$, were below RASW of $15 \%$. Given the fast development of roots by pearl millet (Menezes et al., 1997), it can be assumed that the fragipan potentially reduced water stress for the plants and wilting of plants could, therefore, be avoided at that early stage.

In addition to the water stress, soil surface temperatures influence plant growth and development (Ong and Monteith, 1985). Germination, emergence, and survival of pearl millet seedlings are problematic when soil surface temperatures reach values above $55^{\circ} \mathrm{C}$ (Peacock et al., 1993). Such temperatures were never reached in Ehenge, while they were reached for at least 7 consecutive days in the reference soil, Omutunda. One probable reason for a lower surface temperature on Ehenge is the higher albedo of the surface of Ehenge. The substrate consists mostly of white, bleached sand, which reflects solar energy and reduces energy transfer to the soil. Moreover, temperature and water are interrelated and water plays a fundamental role for energy transfer in soils. The presence of water at low potential enables a better regulation of the soil temperature, through water movement and evaporation (Alkhaier et al., 2012). 


\subsection{Excess water during rainy season}

Given the low amount of rainfall required to reach high RASW values in Ehenge $(76 \mathrm{~mm}$ in $4 \mathrm{~d}$ resulting in RASW around $200 \%$ ), it seems probable that the E horizon experiences excess water conditions in most years. This assumption is also supported by the evidence of iron depletion in this eluvial layer. Redox depletions form when $\mathrm{Fe}(\mathrm{III})$ is reduced to $\mathrm{Fe}$ (II) under water-saturated conditions. The reduced Fe(II) is highly soluble and moved out of the E horizon into soil layers below (Vepraskas and Lindbo, 2012). Based on our data and the rainfall record at Omahenene, the excess water most likely occurred already during the intense rains of December and January, with $131 \mathrm{~mm}$ in $15 \mathrm{~d}$ (from 24 November 2013) and $111 \mathrm{~mm}$ in $4 \mathrm{~d}$ (from 14 January 2014). The high water contents in the whole soil profile of Ehenge during the entire rainy season can, therefore, be attributed to the high infiltration rates of the overlying sand layers and the restricted deep percolation through the less permeable fragipan. In contrast, RASW values in Omutunda never reached $100 \%$ during the measurement period, which we attribute to the absence of water infiltration restricting layers. In Ehenge, RASW values at 25 and $42 \mathrm{~cm}$, above the fragipan, react fast and strongly to rains and dry spells, with faster response time the higher up in the profile. Such strong changes were not observed in the Omutunda soil, because higher clay contents most probably reduced infiltration rates (Saxton and Rawls, 2006), and potentially increased water runoff, in comparison to Ehenge, leading to an attenuated signal of the rainfall in the RASW data.

High soil water contents can create hypoxic conditions, which in turn can strongly limit plant development (Araki et al., 2012). It is therefore comprehensible that the crop yield on Ehenge was very small in 2014, most likely as a consequence of intense and prolonged rainfall (personal field observations and interviews). The long periods of excess water in the soil lead to a delayed development of the plants, which then did not reach maturity in time before the end of the growing season. The measurement of excess water in the soil in combination with low crop yields at the end of the growing season corroborates the perception of the local farmers, who describe the soil as too wet and not profitable during years with average rainfall. However, the moisture development in Ehenge during the identified dry periods shows that this situation of excess water and reduced crop production does not occur during drought years.

\subsection{Dry season and grain maturity}

The dry season started on the 12 April, which most likely corresponds to the plant pollination (approximately $100 \mathrm{~d}$ after sowing), followed by "milk stage" or grain-filling stage, which plays a major role for the final harvest (Maman et al., 2004; Vadez, 2014). The fragipan in the Ehenge remained moist until 8 June, which was $57 \mathrm{~d}$ after the last rainfall. Sim- ilarly to the effect during the summer dry period at the beginning of the measurements, this storage of water could most probably be very important in order to sustain and enable good grain filling during droughts. This is in contrast to the water situation in Omutunda, where the soil showed lower RASW values very soon (RASW below $30 \%$ at all depths on 9 May, while $80 \%$ of RASW was still observed at 42 and $51 \mathrm{~cm}$ in Ehenge), despite the high amounts of rainfall. Considering that a very conservative RASW value of $15 \%$ was chosen to mark water stress, it is plausible to assume that the positive impact of the fragipan through water storage during droughts is even more important than observed in this study.

The positive effect of the fragipan on plant-available water becomes even more meaningful, taking into account that maximum soil surface temperatures were about $5^{\circ} \mathrm{C}$ lower on Omutunda than on Ehenge, causing less evaporation during the later stage of the growing season. On Omutunda, the plants were much better developed than on Ehenge (field observations) so that the soil surface was protected from solar radiation by the plant, creating cooler conditions on the ground. However, in drought years, the reverse of this effect would be apparent, when sparse cover and dark colours cause greater temperatures in Omutunda. This relationship is visible in the higher temperature records at the beginning of the measurements, when Omutunda carried only sparse vegetation (see Sect. 4.1).

\subsection{Derived conceptual model}

The soil moisture and soil surface temperature records observed in this study, combined with the soil properties, can be used to explain the soil hydrology of the Ehenge and the use of the soil by local farmers. The combination of (i) flat landscape position, (ii) sandy topsoil layer, and (iii) nearly impermeable fragipan at shallow depth is the main cause of both the hydrological advantages and disadvantages of the Ehenge. A flat landscape position reduces possibilities for water loss through overland and lateral subsurface flows, which can reach very high volumes, especially if infiltration ratios are as low as $30 \%$, as they were observed in sandy soils at micro-level scale (Gaze et al., 1997), below $70 \%$ (Amogu et al., 2015) or $65 \%-85 \%$ (Orchard et al., 2013) at a catchment scale.

The high hydraulic conductivity and low water retention capacity of sandy layers result in low field capacity $\left(\theta_{\mathrm{FC}}\right)$ and infiltration of rainwater into deep soil layers. In Ehenge, this downward movement is restricted by the fragipan that has very low hydraulic conductivity. The fragipan limits water losses through deep drainage but leads to an excess accumulation of water in the above soil profile, resulting in the development of the iron-depleted $\mathrm{E}$ horizon and frequent hypoxic conditions in periods with high rainfall amounts. This situation restricts plant growth and reduces potential crop yields.

During short dry periods in summer, the high evaporation (high temperatures and radiation) leads to fast drying of 
Ehenge, down to the E horizon $(42 \mathrm{~cm})$. The water stored in the fragipan remains protected from atmospheric conditions by low capillary suction forces due to the overlying sand layers. In particular, the E horizon with $100 \%$ sand content acts as a capillary barrier. Retarded and reduced evaporation was, for example, observed in an experiment by Menziani et al. (1999) on beach sand at depths of 35 and $45 \mathrm{~cm}$.

The slightly alkaline $(\mathrm{pH}=8.5)$, slightly saline $\left(\mathrm{EC}=1.3 \mathrm{dS} \mathrm{m}^{-1}\right)$, and compacted conditions (soil bulk density $\sim 1.7 \mathrm{~g} \mathrm{~cm}^{-3}$ ) in the fragipan do not significantly hinder root development (Hazelton and Murphy, 2007; Sharma and Arora, 2010), due to its soft condition when moist. The access of roots to the water in this layer contradicts Lamotte et al. (1997), who suggested that fragipans limit root development. In order to fulfil its positive role, the fragipan should be positioned neither too deep nor too shallow in the soil profile, allowing young plants to reach the stored water and to reduce the threat of hypoxic conditions. Most farmers explained that the fragipan (Olumha) is found at a depth between a few decimetres and $1 \mathrm{~m}$.

\subsection{Improvement of soil water properties in north-central Namibia}

In order to improve crop productivity in north-central Namibia, two very important soil hydrological aspects would need to be improved: (i) reduction of water stress and (ii) reduction of time with hypoxic conditions in the root zone of the crop. Because of the water storage capacity of the fragipan, crops are less sensitive to droughts in Ehenge soils. However, this soil is very disadvantageous in terms of low nutrient contents and frequent hypoxic conditions as described above.

Rockström et al. (2010) suggest that it is necessary to avoid excess water to make crop productivity economically viable for farmers. Active drainage by deep ripping or installation of drainage pipes seems the most efficient way; however, the desired drainage system would also need to preserve the water storage capacity of the fragipan. Otherwise, its beneficial effect during droughts would be lost. In recent years, deep ripping was introduced and promoted in north-central Namibia, but so far, no scientific literature could be found that proves its benefits, despite numerous claims (e.g. Hase, 2013). In the studied Ehenge, the use of a ripper could have a beneficial agronomic impact if it reaches the fragipan at a depth below $50 \mathrm{~cm}$. It would loosen up the upper part of the fragipan and most likely increase its ability to store water. However, in case of heavy rainfalls, the soil would most probably still experience hypoxic conditions, because the ripper would not completely penetrate the fragipan to allow for deep drainage of the excess water. Furthermore, it is likely that the rill in the fragipan would collapse due to the liquefaction or swelling and shrinking processes of the fragipan in wet conditions. Hence, the expensive and machine-intensive ripping process would have to be repeated frequently. There- fore, we assume that ripping of the fragipan in north-central Namibia would not be an ideal solution to the problem of Ehenge.

\section{Conclusions}

The results presented in this study indicate that the fragipan found in Ehenge soils in north-central Namibia creates a water reservoir in the soil profile, which can be crucial during droughts to sustain crops. Composed of a sandy layer overlying a fragipan, Ehenge remains productive during droughts due to this combination of layers and their interaction with water: sandy topsoil layers enable water to percolate quickly down to the fragipan and they create a capillary barrier for the water stored in the fragipan and thus protect it from evaporation. The fragipan below the sandy topsoil prevents deep percolation of water and enables the storage of high quantities of water that is available to plants during drought periods. An additional effect of the water is the cooling of the soil during hot summer days, which in turn additionally reduces evaporation of valuable water.

Food security is the main concern of farmers in northern Namibia during dry years. Therefore, the presented results clearly emphasize the advantages of farming Ehenge. Soil water is not the only factor limiting productivity, and diseases and poor nutrient balance are important issues as well. However, sufficient and not excessive soil water content may promote nutrient-oriented management improvements on Ehenge by farmers, certainly not the other way around. For example, enhancing drainage through fragipans to enable the use of Ehenge during wet years or increasing crop yields by using a combination of soil maps with accurate weather data to make smart decisions on which fields should be planted and fertilized under certain conditions could perhaps improve the situation for farmers.

The results of this study also have wider implications for small-scale subsistence farming in drylands. Found in many semi-arid areas worldwide, soils with fragipans can have advantageous properties in regards to water storage during droughts. Appropriate techniques that balance the negative effects of hypoxic conditions during wet seasons with the positive effects of the fragipan during drought could improve their productivity and benefit farmers significantly by ensuring food security in regions with high inter-annual rainfall variability. With climate change leading to even greater variability of rainfall in southern Africa, combining the knowledge systems of local farmers, soil scientists, and agronomists offers the possibility to develop such balanced approaches. 


\section{Appendix A: Calculation of surface soil temperature}

Soil temperature was recorded every minute within the measurement period. Since the soil surface temperature is more important for plant growth than the soil temperature itself, it was calculated following the method by Hillel (1998, pp. 309-316). The daily temperature amplitude at the soil surface is calculated with

$A_{0}=A_{5} e^{\frac{0.05}{d}}$

where $A_{5}$ and $A_{0}$ are the temperature amplitude at $5 \mathrm{~cm}$ and at the soil surface, respectively, and $d$ is the characteristic attenuating depth determined by

$d=\sqrt{\frac{P D_{\mathrm{H}}}{\pi}}$.

$P$ the periodicity ( $24 \mathrm{~h}$ in a daily cycle) and $D_{\mathrm{H}}$ thermal diffusivity determined by

$D_{\mathrm{H}}=\max$,

where $K_{\mathrm{h}}$ is the thermal conductivity, $\rho_{\mathrm{b}}$ and $\rho_{\mathrm{p}}$ the bulk soil and the soil particle density, $\Theta=\frac{\theta-\theta_{r}}{\theta_{\text {sat }}-\theta_{r}}$ the saturation status $K_{\mathrm{h}}^{\text {dry }}=\frac{0.135 \rho_{\mathrm{b}}+64.7}{2700-0.947 \rho_{\mathrm{b}}}, K_{\mathrm{h}_{\mathrm{q}}}=7.7, K_{\mathrm{h}_{0}}$ and $K_{\mathrm{h}_{\mathrm{w}}}=0.57$ the thermal conductivity [in $\mathrm{Wm}^{-1} \mathrm{~K}^{-1}$ ] of dry soil, quartz, nonquartz minerals, and water, $\phi=1-\frac{\rho_{\mathrm{b}}}{\rho_{\mathrm{p}}}$ the porosity, and $\alpha$ a fitting parameter ( 0.7 for coarse soils to 1 for fine soils). In the soils under consideration, the major proportion of minerals is quartz (even in the fine fractions; $q=1$ ), and the $K_{\mathrm{h}_{0}}$ parameter was therefore dropped.

Data availability. The data and code used for this paper are available from Zenodo (https://doi.org/10.5281/zenodo.5163714, Prudat, 2021).

Supplement. The supplement related to this article is available online at: https://doi.org/10.5194/gh-77-39-2022-supplement.

Author contributions. Conceptualization of the manuscript was done by BP, NJK, and WF. Writing of original version (BP, WF) and visualization (BP, JK, WF) were carried out before the reviews by WF, JK, LB, and NJK. Investigation, data curation, and formal analysis were performed by BP. Research methodology was worked out by BP and NJK. Acquisition of funding and supervision were carried out of by LB and NJK. Project administration was taken care of by LB.

Competing interests. The contact author has declared that neither they nor their co-authors have any competing interests.
Disclaimer. Publisher's note: Copernicus Publications remains neutral with regard to jurisdictional claims in published maps and institutional affiliations.

Acknowledgements. We would like to thank our colleagues from the Polytechnic of Namibia for their support during the research and the staff of the local administration for facilitating the work. We also thank the farmers who allowed us to use their fields for our research.

Financial support. This work was supported by the Swiss National Science Foundation (grant no. 10001AL_140433) and the German Research Foundation (grant no. DO 1692/1-1).

Review statement. This paper was edited by Cristian Scapozza and reviewed by two anonymous referees.

\section{References}

Ali, M., Jensen, C. R., Mogensen V. O., and Bahrun A.: Drought adaptation of field grown wheat in relation to soil physical conditions, Plant Soil, 208, 1, 149-159, https://https://doi.org/10.1023/A:1004535819197, 1999.

Alkhaier, F., Flerchinger, G. N., and Su, Z.: Shallow groundwater effect on land surface temperature and surface energy balance under bare soil conditions: modeling and description, Hydrol. Earth Syst. Sci., 16, 1817-1831, https://doi.org/10.5194/hess-16-18172012, 2012.

Amogu, O., Esteves, M., Vandervaere, J.-P., Malam Abdou, M., Panthou, G., Rajot, J.-L., Souley Yero, K., Boubkraoui, S., Lapetite, J.-M., Dessay, N., Zin, I., Bachir, A., Bouzou Moussa, I., Faran Maïga, O., Gautier, E., Mamadou, I., and Descroix, L.: Runoff evolution due to land-use change in a small Sahelian Catchment, Hydrol. Sci. J., 60, 78-95, https://doi.org/10.1080/02626667.2014.885654, 2015.

Araki, H., Hossain, M. A., and Takahashi, T.: Waterlogging and Hypoxia have Permanent Effects on Wheat Root Growth and Respiration, J. Agron. Crop. Sci., 198, 264-275, https://doi.org/10.1111/j.1439-037X.2012.00510.x, 2012.

Central Bureau of Statistics: Report on the Annual Agricultural Surveys 1996-2003: Basic Analysis of Communal Agriculture, Survey, National Planning Commission, Windhoek, Namibia, 2003.

Chartres, C. J.: A Preliminary Investigation of Hardpan Horizons in North-West New South Wales, Soil Res., 23, 325-337, 1985.

Dane, J. H. and Topp, G. C.: Methods of Soil Analysis, Part 4: Physical Methods, Book Series 5, Madison, Wisconsin, USA, Soil Sci. Soc. Am., 2002.

Daniells, I. G.: Hardsetting Soils: A Review, Soil Res., 50, 349-59, 2012.

Francis, M. L., Fey, M. V., Prinsloo, H. P., Ellis, F., Mills, A. J., and Medinski, T. V.: Soils of Namaqualand: Compensations for aridity, J. Arid Environ., 70, 588-603, https://doi.org/10.1016/j.jaridenv.2006.12.028, 2007.

Gaze, S. R., Simmonds, L. P., Brouwer, J., and Bouma, J.: Measurement of surface redistribution of rainfall and modelling its effect on water balance calculations for a millet 
field on sandy soil in niger, J. Hydrol., 188-189, 267-284, https://doi.org/10.1016/S0022-1694(96)03162-9, 1997.

Hase, F. v.: Facilitating Conservation Agriculture in Namibia through Understanding Farmers' Planned Behaviour and Decision Making, Master thesis, Swedish University of Agricultural Sciences, Alnarp, Sweden, available at: https://stud.epsilon.slu. se/6041/ (last access: 28 December 2021), 2013.

Hazelton, P. A. and Murphy, B. W.: Interpreting Soil Test Results: What Do All the Numbers Mean?, CSIRO PUBLISHING, Collingwood VIC 3066, Australia, 2007.

Hillel, D.: Environmental Soil Physics: Fundamentals, Applications, and Environmental Considerations, Academic press, San Diego, USA, 1998.

Hillyer, A. E. M., McDonagh, J. F., and Verlinden, A.: Landuse and legumes in northern Namibia - The Value of a local classification system, Agr. Ecosyst. Environ., 117, 251-265, https://doi.org/10.1016/j.agee.2006.04.008, 2006.

IPCC Climate Change 2021: The Physical Science Basis. Contribution of Working Group I to the Sixth Assessment Report of the Intergovernmental Panel on climate Change, edited by: Masson-Delmotte, V., Zhai, P., Pirani, A., Connors, S. L., Péan, C., Berger, S., Caud, N., Chen, Y., Goldfarb, L., Gomis, M. I., Huang, M., Leitzell, K., Lonnoy, E., Matthews, J. B. R., Maycock, T. K., Waterfield, T., Yelekçi, O., Yu, R., and Zhou, B., Cambridge University Press, in press, available at: https://www. ipcc.ch/report/ar6/wg1/, last access: 25 August 2021.

IUSS Working Group WRB: World reference base for soil resources 2014, International soil classification system for naming soils and creating legends for soil maps, 106, World Soil Resources Reports, FAO, Rome, available at: http://www.fao.org/soils-portal/soil-survey/soil-classification/ world-reference-base/en/ (last access: 28 December 2021), 2014.

Jensen, C. R., Mogensen, V. O., Poulsen, H.-H., Henson, I. E., Aagot, S., Hansen, E., Ali, M., and Wollenweber, B.: Soil water matric potential rather than water content determines drought responses in field-grown lupin (Lupinus Angustifolius), Funct. Plant Biol., 25, 353-363, 1998.

Keyler, S.: Economics of the Pearl Millet Subsector in Northern Namibia: A Summary of Baseline Data, ICRISAT, Southern and Eastern Africa Region Working Paper, 95/03, Sorghum and Millet improvement Program, Bulawayo Zimbabwe, 1995.

Kizito, F., Dragila, M., Sene, M., Lufafa, A., Diedhiou, I., Dick, R. P., Selker, J. S., Dossa, E., Khouma, M., and Badiane, A.: Seasonal soil water variation and root patterns between two semi-arid shrubs co-existing with Pearl millet in Senegal, West Africa, J. Arid Environ., 67, 436-455, https://doi.org/10.1016/j.jaridenv.2006.02.021, 2006.

Krogh, L. and Paarup-Laursen, B.: Indigenous soil knowledge among the Fulani of northern Burkina Faso: linking soil science and anthropology in analysis of natural resource management, GeoJournal, 43, 189-197, https://doi.org/10.1023/A:1006894818609, 1997.

Lamotte, M., Bruand, A., Humbel, F., Herbillon, A., and Rieu, M.: A hard sandy-loam soil from semi-arid northern Cameroon: I. Fabric of the groundmass, Eur. J. Soil Sci., 48, 213-225, https://doi.org/10.1111/j.1365-2389.1997.tb00542.x, 1997.

Leenaars, J. G. B., Hengl, T., Ruiperez González, M., Mendes de Jesus, J. S., Heuvelink, G. B. M., Wolf, J., van Bussel, L. G. J.,
Claessens, L., Yang, H., and Cassman, K. G.: Root Zone PlantAvailable Water Holding Capacity of the Sub-Saharan Africa Soil, Gridded functional soil information (data set RZ-PAWHC SSA v. 1.0), ISRIC - World Soil Information, Wageningen, Netherlands, 2015.

Maman, N., Mason, S. C., Lyon, D. J., and Dhungana, P.: Yield Components of Pearl Millet and Grain Sorghum across Environments in the Central Great Plains, Crop Sci., 44, 2138-2145, https://doi.org/10.2135/cropsci2004.2138, 2004.

Mendelsohn, J., El Obeid, S., and Roberts, C.: A Profile of NorthCentral Namibia, Gamsberg Macmillan Publishers, Windhoek, Namibia, 2000.

Mendelsohn, J., Jarvis, A., and Robertson, T.: A Profile and Atlas of the Cuvelai-Etosha Basin, RAISON \& Gondwana Collection, Windhoek, Namibia, 2013.

Menezes, R. S. C., Gascho, G. J., Hanna, W. W., Cabrera, M. L., and Hook, J. E.: Subsoil nitrate uptake by grain pearl millet, Agron. J., 89, 189-194, 1997.

Menziani, M., Pugnaghi, S., Pilan, L., Santangelo, R., and Vincenzi, S.: Field experiments to study evaporation from a saturated bare soil, Phys. Chem. Earth Pt. B, 24, 813-818, https://doi.org/10.1016/S1464-1909(99)00086-6, 1999.

Miller, R. M., Pickford, M., and Senut, B.: The geology, palaeontology and evolution of the Etosha Pan, Namibia: implications for terminal Kalahari deposition, S. Afr. J. Geol. 113, 307-334, 2010.

Nemes, A., Pachepsky, Y. A., and Timlin, D. J.: Toward Improving Global Estimates of Field Soil Water Capacity, Soil Sci. Soc. Am. J., 75, 807-812, https://doi.org/10.2136/sssaj2010.0251, 2011.

Niemeijer, D. and Mazzucato, V.: Moving beyond indigenous soil taxonomies: local theories of soils for sustainable development, Geoderma, 111, 403-424, https://doi.org/10.1016/S00167061(02)00274-4, 2003.

Ong, C. K. and Monteith, J. L.: Response of pearl millet to light and temperature, Field Crop. Res., 11, 141-160, https://doi.org/10.1016/0378-4290(85)90098-X, 1985.

Orchard, C. M., Lorentz, S. A., Jewitt, G. P. W., and Chaplot, V. M.: Spatial and temporal variations of overland flow during rainfall events and in relation to catchment conditions, Hydrol. Process., 27, 2325-2338, https://doi.org/10.1002/hyp.9217, 2013.

Peacock, J. M., Soman, P., Jayachandran, R., Rani, A., Howarth, C., and Thomas, A.: Effects of High Soil Surface Temperature on Seedling Survival in Pearl Millet, Exp. Agr., 29, 215-225, https://doi.org/10.1017/S0014479700020664, 1993.

Prudat, B., Bloemertz, L., and Kuhn, N. J.: Local soil quality assessment of north-central Namibia: integrating farmers' and technical knowledge, SOIL, 4, 47-62, https://doi.org/10.5194/soil-447-2018, 2018.

Prudat, B., Bloemertz, L., Graefe, O., and Kuhn, N. J.: Soil classifications. Between material facts and socio-ecological narratives, in: Towards shared research. Participatory and integrative approaches in Researching African Environments, edited by: Haller, T. and Zingerli, C., Transcript, Bielefeld, 25-43, 2020.

Prudat, B., Fister, W., Bloemertz, L., Krenz, J., and Kuhn, N. J.: The Potential of Fragipans in Sustaining Pearl Millet during Drought Periods in North-Central Namiba, Zenodo [data set], https://doi.org/10.5281/zenodo.5163714, 2021. 
Quinones, H., Ruelle, P., and Nemeth, I.: Comparison of three calibration procedures for TDR soil moisture sensors, Irrig. and Drain., 52, 203-217, https://doi.org/10.1002/ird.95, 2003.

Rockström, J. and De Rouw, A.: Water, nutrients and slope position in on-farm pearl millet cultivation in the Sahel, Plant Soil, 195, 311-327, https://doi.org/10.1023/A:1004233303066, 1997.

Rockström, J., Karlberg, L., Wani, S. P., Barron, J., Hatibu, N., Oweis, T., Bruggeman, A., Farahani, J., and Qiang, Z.: Managing water in rainfed agriculture-The need for a paradigm shift, Agr. Water Manage., 97, 543-550, https://doi.org/10.1016/j.agwat.2009.09.009, 2010.

Rukandema, M., Breen, J., Fanikiso, M., and Sanchis, P. H.: Crop, Livestock and Food Security Assessment Mission to Namibia, FAO/WFP, Rome, available at: $\quad$ https://reliefweb.int/sites/reliefweb.int/files/resources/ 6DB55B921A88EED9852575F20065F5E0-Full_Report.pdf (last access: 28 December 2021), 32 pp., 2009.

Rurinda, J., Mapfumo, P., van Wijk, M. T., Mtambanengwe, F., Rufino, M. C., Chikowo, R., and Giller, K. E.: Managing soil fertility to adapt to rainfall variability in smallholder cropping systems in Zimbabwe, Field Crop. Res., 154, 211-225, https://doi.org/10.1016/j.fcr.2013.08.012, 2013.

Saxton, K. E. and Rawls, W. J.: Soil Water Characteristic Estimates by Texture and Organic Matter for Hydrologic Solutions, Soil Sci. Soc. Am. J., 70, 1569-1578, https://doi.org/10.2136/sssaj2005.0117, 2006.

Sharma, A. and Arora, S.: Soil Quality Indices and Relative Production Efficiency for Maize and Wheat Crops in Agroclimates of Northwest India, Soil Sci., 175, 44-49, https://doi.org/10.1097/SS.0b013e3181cb478a, 2010.

Sivakumar, M. V. K.: Weather and Climate Extremes: Need for and importance of the journal, Weather and Climate Extremes, 1, 13, https://doi.org/10.1016/j.wace.2013.08.002, 2013.
Soil Survey Staff: Soil Taxonomy: A Basic System of Soil Classification for Making and Interpreting Soil Surveys, 2nd edn., vol. 436, Natural Resources Conservation Service, U.S. Department of Agriculture, Soil Conservation Service, US Department of Agriculture, Soil Conservation Service, Washington USA, 1999.

Sun, Z. J., Young, G. D., McFarlane, R. A., and Chambers, B. M.: The effect of soil electrical conductivity on moisture determination using time-domain reflectometry in sandy soil, Can. J. Soil Sci., 80, 13-22, https://doi.org/10.4141/S98-089, 2000.

Vadez, V.: Root hydraulics: The forgotten side of roots in drought adaptation, Field Crop. Res., 165, 15-24, https://doi.org/10.1016/j.fcr.2014.03.017, 2014.

van Genuchten, M. Th.: A Closed-form Equation for Predicting the Hydraulic Conductivity of Unsaturated Soils, Soil Sci. Soc. Am. J., 44, 892-980, 1980.

Vanlauwe, B., Descheemaeker, K., Giller, K. E., Huising, J., Merckx, R., Nziguheba, G., Wendt, J., and Zingore, S.: Integrated soil fertility management in sub-Saharan Africa: unravelling local adaptation, SOIL, 1, 491-508, https://doi.org/10.5194/soil-1491-2015, 2015.

Vepraskas, M. J. and Lindbo, D. L.: Chapter 5: Redoximorphic Features as Related to Soil Hydrology and Hydric Soils, 143-172, in: Hydropedology, Synergistic integration of soil science and hydrology, edited by: Lin, H., Elsevier, Oxford, 2012.

Vereecken, H., Huisman, J. A., Bogena, H., Vanderborght, J., Vrugt, J. A., and Hopmans, J. W.: On the value of soil moisture measurements in vadose zone hydrology: A Review, Water Resour. Res., 44, W00D06, https://doi.org/10.1029/2008WR006829, 2008.

Zegada-Lizarua, W. and Iijima M.: Deep Root Water Uptake Ability and Water Use Efficiency of Pearl Millet in Comparison to Other Millet Species, Plant Prod. Sci., 8, 454-460, https://doi.org/10.1626/pps.8.454, 2005. 